\title{
Estimation of the Major Source and Sink of Methylmercury in the Florida Everglades
}

\author{
Yanbin Li, ${ }^{\dagger \dagger}$ Yongguang Yin, ${ }^{\|}$Guangliang Liu, ${ }^{\dagger, \ddagger}$ Georgio Tachiev, ${ }^{\S}$ David Roelant, ${ }^{\S}$ Guibin Jiang, \\ and Yong Cai ${ }^{*},+,+$
} ${ }^{\dagger}$ Department of Chemistry \& Biochemistry, ${ }^{\ddagger}$ Southeast Environmental Research Center, and ${ }^{\S}$ Applied Research Center, Florida
International University, Miami, Florida, 33199, United States
${ }^{\|}$State Key Laboratory of Environmental Chemistry and Ecotoxicology, Research Center for Eco-Environmental Sciences, Chinese
Academy of Sciences, Beijing, 100085, China

Supporting Information

\begin{abstract}
Mercury methylation and/or demethylation have been observed in several compartments [soil (saturated soils covered by standing water), floc, periphyton, and water] of the Everglades, a wetland with mercury as one of the major water quality concerns. However, it is still unclear which compartment is the major source or sink due to the lack of estimation and comparison of the net methylmercury $(\mathrm{MeHg})$ production or degradation in these compartments. The lack of this information has limited our understanding of $\mathrm{Hg}$ cycling in this ecosystem. This study adopted a double stable isotope $\left({ }^{199} \mathrm{Hg}^{2+}\right.$ and $\left.\mathrm{Me}^{201} \mathrm{Hg}\right)$ addition technique to determine the methylation/demethylation rate constants and the net $\mathrm{MeHg}$ production rates in each compartment. This study improved the previous models for estimating these parameters by (1) taking into

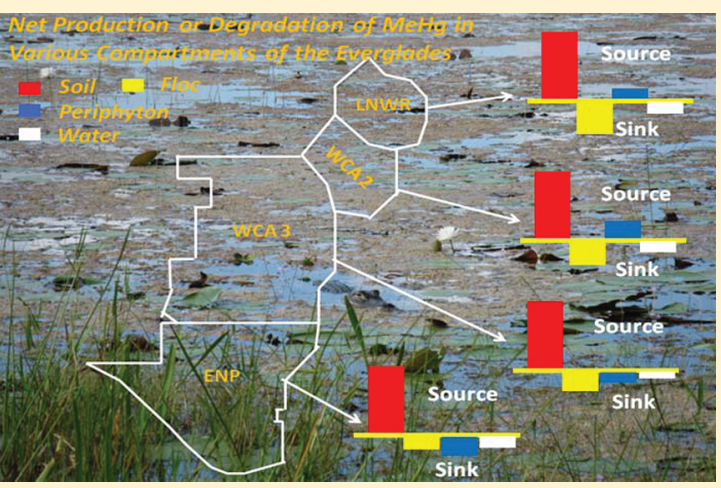
account the difference between newly input and ambient mercury in methylation/demethylation efficiency and (2) correcting the contribution of photodemethylation to $\mathrm{Me}^{199} \mathrm{Hg}$ concentration when calculating methylation rates in water. The net $\mathrm{MeHg}$ production rate in each compartment was then estimated to identify the major sources and sinks of $\mathrm{MeHg}$. The results indicate that these improvements in modeling are necessary, as a significant error would occur otherwise. Soil was identified to be the largest source of $\mathrm{MeHg}$ in the Everglades, while the floc and water column were identified as the major sinks. The role of periphyton varies, appearing to be a source in the northern Everglades and a sink in the southern Everglades. Soil could be the largest source for $\mathrm{MeHg}$ in the water column, while methylation in periphyton could also contribute significantly in the northern Everglades.
\end{abstract}

\section{INTRODUCTION}

Over the last several decades, methylmercury $(\mathrm{MeHg})$ has emerged as one of the most widespread contaminants due to its prevalent existence, high toxicity, and bioaccumulation through the food chain. As a crucial part of understanding the cycling of mercury $(\mathrm{Hg})$, great efforts have been made to identify the major production and degradation processes of $\mathrm{MeHg}$ in aquatic systems. Methylation of $\mathrm{Hg}$ in sediment by anaerobic bacteria (sulfate-reducing bacteria ${ }^{1}$ or iron-reducing bacteria ${ }^{2}$ ) was deemed to be the major pathway for $\mathrm{MeHg}$ production ${ }^{2-7}$ in most aquatic systems, while photodemethylation in water was widely proposed to be the major process of $\mathrm{MeHg}$ elimination. ${ }^{8,9}$ Methylation of inorganic mercury in the water column was reported to be another significant pathway of $\mathrm{MeHg}$ formation in some ocean (e.g., the $\operatorname{Arctic}^{10}$ ) and freshwater ${ }^{11}$ systems.

The double stable isotope addition technique is a useful tool for measuring $\mathrm{Hg}$ methylation/demethylation rates owing to its high accuracy, precision, and simultaneous determination of the methylation and demethylation rates. In recent years, this technique has been widely applied in estimating the net production of $\mathrm{MeHg}$. However, two significant defects exist in previous models using this technique for identifying the major source and sink of $\mathrm{MeHg}$. One is omission of the difference between the ambient and newly input $\mathrm{Hg}$ species in methylation/demethylation efficiency. ${ }^{12}$ Their difference was often neglected in previous studies on estimating the net $\mathrm{MeHg}$ production rate. ${ }^{13,14} \mathrm{~A}$ significant error could occur with this omission because a significant difference in methylation efficiency has been reported. ${ }^{15}$ The other defect is related to the calculation of $\mathrm{Hg}$ methylation rate constant of the spiked mercury tracer $\left(k_{\mathrm{m}}\right)$ in water. This constant was usually calculated by the measured per-day increase in the amount of $\mathrm{Me}^{n} \mathrm{Hg}$ (with the assumption that ${ }^{n} \mathrm{Hg}^{2+}$ was spiked). ${ }^{16,17}$ This calculation assumes that the degradation of ambient and newly

Received: December 9, 2011

Revised: April 23, 2012

Accepted: April 26, 2012

Published: April 26, 2012 
produced $\mathrm{Me}^{n} \mathrm{Hg}$ is negligible. However, this assumption often may not be valid for natural waters, where $\mathrm{MeHg}$ demethylation rate constant $\left(k_{\mathrm{d}}\right)$ can be $2-3$ orders larger than $k_{\mathrm{m}} \cdot{ }^{10}$ These two defects should be corrected for an accurate estimation of the production or degradation of $\mathrm{MeHg}$ by utilizing stable isotope tracer techniques.

The Everglades is a subtropical wetland ecosystem located in the south of Florida. Great efforts have been made to understand the cycling of mercury in this system ${ }^{9,12,18-20}$ since the observation of elevated mercury levels in fish, wading birds, and other wildlife. ${ }^{21} \mathrm{Hg}$ methylation and/or $\mathrm{MeHg}$ demethylation were found to occur in various compartments of the Everglades, including soil, ${ }^{12,20}$ floc (flocculent materials on top of soil), ${ }^{19}$ periphyton, ${ }^{18}$ and water. ${ }^{9}$ Despite these findings, it is still unclear which compartment is the major source or sink of $\mathrm{MeHg}$ due to the lack of estimation and comparison of the net $\mathrm{MeHg}$ production in these compartments. A few previous studies have investigated the relationship of $\mathrm{MeHg}$ distribution in a certain compartment of the Everglades to its in situ methylation or demethylation. The spatial pattern of $\mathrm{MeHg}$ was previously found to be positively related to that of $\mathrm{MeHg}$ methylation rate in Everglades soil. ${ }^{12} \mathrm{MeHg}$ concentration in Everglades water was reported to be negatively related to photodemethylation in water. ${ }^{9}$ Nevertheless, there is a lack of knowledge on the relationships of $\mathrm{MeHg}$ in a certain compartment to methylation/demethylation in other compartments. This information is crucial since $\mathrm{MeHg}$ present in one compartment (e.g., water) could be determined by the methylation/demethylation occurring both in that compartment and in other compartments (e.g., floc, periphyton, or soil).

The objectives of this study were to investigate $\mathrm{Hg}$ methylation/demethylation in various compartments of the Everglades, to assess the role of these processes in the spatial distribution of $\mathrm{MeHg}$, and to identify the major source and major sink of $\mathrm{MeHg}$ in this ecosystem. To achieve these objectives, double stable isotope $\left({ }^{199} \mathrm{Hg}^{2+}\right.$ and $\left.\mathrm{Me}^{201} \mathrm{Hg}\right)$ addition experiments were conducted to study the methylation/demethylation of mercury in various compartments and areas of the Everglades. The net production or degradation rates of ambient and newly input $\mathrm{Hg}$ were calculated in soil, periphyton, floc, and water of the Everglades.

\section{MATERIALS AND METHODS}

Reagents. $\mathrm{MeHgCl}$ standard was purchased from Ultra Scientific (N. Kingstown, RI). Enriched ${ }^{201} \mathrm{HgO}$ (atomic percentage $96.17 \% \pm 0.56 \%$ ) and ${ }^{199} \mathrm{HgO}$ (atomic percentage, $91.09 \% \pm 0.05 \%)$ were purchased from Oak Ridge National Laboratory (Oak Ridge, TN). ${ }^{199} \mathrm{HgCl}_{2}$ solution (measured atomic percentage $91.19 \% \pm 0.46 \%$ ) was prepared by dissolving ${ }^{199} \mathrm{HgO}$ in $10 \% \mathrm{HCl}(\mathrm{v} / \mathrm{v}) . \mathrm{Me}^{201} \mathrm{HgCl}$ (measured atomic percentage $93.25 \% \pm 0.42 \%)$ was synthesized from isotopeenriched ${ }^{201} \mathrm{HgO}$ by use of methylcobalamin. ${ }^{22}$ Other reagents used were of reagent grade or higher.

Collection of Samples. Unfiltered surface water was collected at five sites in September-October 2009 to study the photodemethylation of $\mathrm{MeHg}$ (results were previously published $)^{9}$ and the methylation of inorganic mercury in water. Soil, floc, and periphyton samples were collected at four sites in September-October 2009 and at 12 sites in July 2010 (Figure S1, Supporting Information) to study the methylation and demethylation of mercury in these compartments. Although covered by water, the term "soil", rather than sediment, is generally used in the literature for most areas of the Everglades except the canals. Detailed sampling procedures can be found in the Supporting Information. Upon arrival of samples at the laboratory, $\mathrm{Hg}$ methylation/demethylation experiments were conducted within $3 \mathrm{~h}$. Trace-metal clean techniques were followed during sample collection, shipment, and analysis. ${ }^{23}$

Incubation Experiments. Methylation and Demethylation of Mercury in Soil, Floc, and Periphyton. Double stable isotope addition method $\left({ }^{199} \mathrm{HgCl}_{2}\right.$ and $\left.\mathrm{Me}^{201} \mathrm{Hg}\right)$ was employed to simultaneously measure the methylation and demethylation rate constants. Soil $(0-10 \mathrm{~cm})$, floc, and periphyton were homogenized with a blender. Predetermined quantity of isotope-enriched ${ }^{199} \mathrm{HgCl}_{2}$ and $\mathrm{Me}^{201} \mathrm{Hg}$ were added to approximately $30 \mathrm{~g}$ of soil $\left(2.03 \mathrm{ng}\right.$ of ${ }^{199} \mathrm{Hg} \cdot \mathrm{g}^{-1}$ and $0.22 \mathrm{ng}$ of ${ }^{201} \mathrm{Hg} \cdot \mathrm{g}^{-1}$ wet sample), floc $\left(0.44 \mathrm{ng}\right.$ of ${ }^{199} \mathrm{Hg} \cdot \mathrm{g}^{-1}$ and 0.17 ng of ${ }^{201} \mathrm{Hg}^{-1}$ wet sample), or periphyton (0.44 ng of ${ }^{199} \mathrm{Hg} \cdot \mathrm{g}^{-1}$ and $0.17 \mathrm{ng}$ of ${ }^{201} \mathrm{Hg} \cdot \mathrm{g}^{-1}$ wet sample). Concentrations of the spiked ${ }^{199} \mathrm{HgCl}_{2}$ and $\mathrm{Me}^{201} \mathrm{Hg}$ were at the ambient total $\mathrm{Hg}$ and $\mathrm{MeHg}$ levels $(0.1-1.7$ times that of ambient total $\mathrm{Hg}$ and $0.3-9.6$ times that of ambient $\mathrm{MeHg}$ ). All these procedures were conducted under a $\mathrm{N}_{2}$ saturated atmosphere. Triplicates were employed for each trial. Spiked samples were divided into two portions, of which one was immediately frozen to $-20{ }^{\circ} \mathrm{C}$, representing $t=0$ days $\left(t_{0}\right)$. The other portion was incubated in darkness at $29 \pm 1{ }^{\circ} \mathrm{C}$ (in situ water temperature ranged from 26 to $31{ }^{\circ} \mathrm{C}$ during the sampling period) under $\mathrm{N}_{2}$ saturated atmosphere for 2 days, representing $t=2$ days $\left(t_{2}\right)$. Samples were collected and preserved at $-20{ }^{\circ} \mathrm{C}$ and then analyzed for $\mathrm{Me}^{199} \mathrm{Hg}, \mathrm{Me}^{201} \mathrm{Hg}$, and $\mathrm{Me}^{202} \mathrm{Hg}$ via aqueous phenylation followed by gas chromatography and inductively coupled plasma mass spectrometry (GC-ICP-MS). ${ }^{24}$

Methylation/Demethylation of Mercury in Everglades Water. Unfiltered water samples $(200 \mathrm{~mL})$ were transferred to 0.5-L FEP (fluorinated ethylene-propylene) Teflon bottles and then spiked with ${ }^{199} \mathrm{HgCl}_{2}$ and $\mathrm{Me}^{201} \mathrm{Hg}$ to form final concentrations of approximately 50 and $0.6 \mathrm{ng} \cdot \mathrm{L}^{-1}$ as $\mathrm{Hg}$, respectively. Spiked samples were divided into two groups and were incubated for 6 days. One group was incubated under ambient temperature and light conditions, while the other was incubated under dark condition by wrapping the bottles with aluminum foil. Triplicates were employed for each trial. After incubation, water samples were preserved by adding concentrated $\mathrm{HCl}$ to form a final concentration of $1 \%(\mathrm{v} / \mathrm{v})$ and were stored at $4{ }^{\circ} \mathrm{C}$ until analysis. Concentrations of $\mathrm{Me}^{199} \mathrm{Hg}$, $\mathrm{Me}^{201} \mathrm{Hg}$, and $\mathrm{Me}^{202} \mathrm{Hg}$ in the incubated samples were determined after $0,2,4$, and 6 days of incubation.

Determination of Total $\mathrm{Hg}, \mathrm{MeHg}$, and Other Ancillary Parameters. Detailed analytical procedures for $\mathrm{MeHg}$, total $\mathrm{Hg}(\mathrm{THg})$, and other ancillary parameters can be found in the Supporting Information.

Data Analysis. Calculation of Specific $\mathrm{Hg}^{2+}$ Methylation/ $\mathrm{MeHg}$ Demethylation Rate Constants in Soil, Floc, and Periphyton. The specific methylation and demethylation rate constants of newly spiked ${ }^{199} \mathrm{Hg}^{2+}$ and $\mathrm{Me}^{201} \mathrm{Hg}\left(k_{\mathrm{m}}\right.$ and $\left.k_{\mathrm{d}}\right)$ and measured net ambient $\mathrm{MeHg}$ production (or degradation) rate $(R)$ in soil, floc, and periphyton were calculated from the increased amount of $\mathrm{Me}^{199} \mathrm{Hg}$ derived from the spiked ${ }^{199} \mathrm{Hg}^{2+}$ $\left(\Delta\left[\mathrm{Me}^{199} \mathrm{Hg}\right]_{\mathrm{sp}}\right)$, the decreased amount of spiked $\mathrm{Me}^{201} \mathrm{Hg}$ $\left(\Delta\left[\mathrm{Me}^{201} \mathrm{Hg}\right]_{\mathrm{sp}}\right)$, and the net change in the amount of ambient $\mathrm{Me}^{202} \mathrm{Hg}\left(\Delta\left[\mathrm{Me}^{202} \mathrm{Hg}\right]_{\mathrm{n}}\right)$, respectively (eqs 1-3). In many previous studies, ${ }^{16}$ the change in concentrations of measured $\mathrm{Me}^{199} \mathrm{Hg}$ and $\mathrm{Me}^{201} \mathrm{Hg}$ were used to substitute for 
$\Delta\left[\mathrm{Me}^{199} \mathrm{Hg}\right]_{\mathrm{sp}}$ and $\Delta\left[\mathrm{Me}^{201} \mathrm{Hg}\right]_{\mathrm{sp}}$ to simplify the calculation. However, this simplification could cause a significant error if the methylation or demethylation of ambient mercury is not negligible. In this study, this defect was overcome by directly calculating the values of $\Delta\left[\mathrm{Me}^{199} \mathrm{Hg}\right]_{\mathrm{sp}}, \Delta\left[\mathrm{Me}^{201} \mathrm{Hg}\right]_{\mathrm{sp}}$, and $\Delta\left[\mathrm{Me}^{202} \mathrm{Hg}\right]_{\mathrm{n}}$ to determine $k_{\mathrm{m}}, k_{\mathrm{d}}$, and $R$. They were calculated from equations similar to previously proposed functions for detecting transformations of $\mathrm{Hg}$ species. ${ }^{25}$ A detailed derivation of these equations is provided in the Supporting Information. A $t$-test was then conducted on measured $k_{\mathrm{m}}, k_{\mathrm{d}}$, and $R$ triplicate values to assess whether the measured methylation/demethylation rates of the spiked and ambient $\mathrm{Hg}$ were statistically significant $(p<0.05$ level $)$.

$$
\begin{aligned}
& k_{\mathrm{m}}=\frac{\Delta\left[\mathrm{Me}^{199} \mathrm{Hg}\right]_{\mathrm{sp}}}{\left[{ }^{199} \mathrm{Hg}^{2+}\right]_{\mathrm{sp}} t} \\
& k_{\mathrm{d}}=\frac{\ln \frac{\left[\mathrm{Me}^{201} \mathrm{Hg}\right]_{\mathrm{sp}}}{\left[\mathrm{Me}^{201} \mathrm{Hg}\right]_{\mathrm{sp}}-\Delta\left[\mathrm{Me}^{201} \mathrm{Hg}\right]_{\mathrm{sp}}}}{t} \\
& R=\frac{\Delta\left[\mathrm{Me}^{202} \mathrm{Hg}\right]_{\mathrm{n}}}{P_{202} t}
\end{aligned}
$$

where $k_{\mathrm{m}}$ is the specific methylation rate constant of spiked ${ }^{199} \mathrm{Hg}^{2+}$ (per day); $k_{\mathrm{d}}$ is the specific demethylation rate constant of spiked $\mathrm{Me}^{201} \mathrm{Hg}$ (per day); $R$ is the measured production ( $R$ $>0$ ) or degradation $(R<0)$ rate of ambient $\mathrm{MeHg}$ (nanograms per gram per day); $t$ is the incubation time (days); $\left[{ }^{199} \mathrm{Hg}^{2+}\right]_{\mathrm{sp}}$ and $\left[\mathrm{Me}^{201} \mathrm{Hg}\right]_{\mathrm{sp}}$ are the concentrations of spiked ${ }^{199} \mathrm{Hg}^{2+}$ and $\mathrm{Me}^{201} \mathrm{Hg}$ (nanograms per gram), respectively; and $P_{202}$ is the natural abundance of ${ }^{202} \mathrm{Hg}$ in ambient mercury $(29.86 \%) .{ }^{26}$

Calculation of Specific $\mathrm{Hg}^{2+}$ Methylation/MeHg Demethylation Rate Constants in Water. A model based on firstorder chemical kinetics was used to describe the degradation of $\mathrm{MeHg}$ in water (eq 4). ${ }^{8,27}$ The rate constant of $\mathrm{MeHg}$ degradation, $k_{\mathrm{d}}$, was then obtained by linear regression of $\ln$ $\left(\left[\mathrm{Me}^{201} \mathrm{Hg}\right]\right)_{t}$ against $t$, using Origin (version 6.0 for Windows; OriginLab Corp., Northampton, MA). A new model was developed to calculate the methylation rate constant of the spiked ${ }^{199} \mathrm{Hg}^{2+}\left(k_{\mathrm{m}}\right)$ in water (eq $\left.5 \mathrm{a}, 5 \mathrm{~b}\right)$. In this model, contributions of both ${ }^{199} \mathrm{Hg}^{2+}$ methylation and $\mathrm{Me}^{199} \mathrm{Hg}$ demethylation are taken into account in the function describing the variation of $\mathrm{Me}^{199} \mathrm{Hg}$ concentration (eq 5a,5b). According to this equation, $k_{\mathrm{m}}$ could be calculated by nonlinear regression of $\left[\mathrm{Me}{ }^{199} \mathrm{Hg}\right]_{t}$ against $t$. However, $\left[\mathrm{Me}^{199} \mathrm{Hg}\right]_{t}$ is not sensitive to the value of $k_{\mathrm{m}}$ in the case of $k_{\mathrm{d}} \gg k_{\mathrm{m}}$, and an error will occur during the regression process under this condition. To correct for this error, a variable with higher sensitivity to the $k_{\mathrm{m}}$ value, $\left[\mathrm{Me}^{199} \mathrm{Hg}\right]_{t} /\left[\mathrm{Me}^{202} \mathrm{Hg}\right]_{t}$ ratio $\left[R_{202}^{199}(t)\right]$, was employed to calculate $k_{\mathrm{m}}$ in water (eq $\left.6 \mathrm{a}, 6 \mathrm{~b}\right)$. This ratio is expected to increase through the incubation period if methylation occurs in water. A detailed derivation of these equations is provided in the Supporting Information.

$$
\ln \left(\left[\mathrm{Me}^{201} \mathrm{Hg}\right]_{t}\right)=\ln \left(\left[\mathrm{Me}^{201} \mathrm{Hg}\right]_{0}\right)-k_{\mathrm{d}} t
$$

When $k_{\mathrm{d}}>0,\left[\mathrm{Me}^{199} \mathrm{Hg}\right]_{t}$ is given by eq $5 \mathrm{a}$

$$
\begin{aligned}
& {\left[\mathrm{Me}^{199} \mathrm{Hg}\right]_{t}} \\
& =\frac{k_{\mathrm{m}}\left[{ }^{199} \mathrm{Hg}^{2+}\right]_{0}-\left(k_{\mathrm{m}}\left[{ }^{199} \mathrm{Hg}^{2+}\right]_{0}-k_{\mathrm{d}}\left[\mathrm{Me}{ }^{199} \mathrm{Hg}\right]_{0}\right) \mathrm{e}^{-k_{\mathrm{d}} t}}{k_{\mathrm{d}}}
\end{aligned}
$$

and when $k_{\mathrm{d}}=0,\left[\mathrm{Me}^{199} \mathrm{Hg}\right]_{t}$ is given by eq $5 \mathrm{~b}$ :

$$
\left[\mathrm{Me}^{199} \mathrm{Hg}\right]_{t}=k_{\mathrm{m}}\left[{ }^{199} \mathrm{Hg}^{2+}\right]_{0} t+\left[\mathrm{Me}^{199} \mathrm{Hg}\right]_{0}
$$

When $k_{\mathrm{d}}>0, R_{202}^{199}(t)$ is given by eq $6 \mathrm{a}$

$$
\begin{aligned}
R_{202}^{199}(t) & =\frac{\left[\mathrm{Me}{ }^{199} \mathrm{Hg}\right]_{t}}{\left[\mathrm{Me}^{202} \mathrm{Hg}\right]_{t}} \\
& =\frac{k_{\mathrm{m}}\left[{ }^{199} \mathrm{Hg}^{2+}\right]_{0}-\left(k_{\mathrm{m}}\left[{ }^{[99} \mathrm{Hg}^{2+}\right]_{0}-k_{\mathrm{d}}\left[\mathrm{Me}^{199} \mathrm{Hg}\right]_{0}\right) \mathrm{e}^{-k_{\mathrm{d}}}}{k_{\mathrm{m}}\left[{ }^{202} \mathrm{Hg}^{2+}\right]_{0}-\left(k_{\mathrm{m}}\left[{ }^{202} \mathrm{Hg}^{2+}\right]_{0}-k_{\mathrm{d}}\left[\mathrm{Me}^{202} \mathrm{Hg}\right]_{0}\right) \mathrm{e}^{-k_{\mathrm{s}}}}
\end{aligned}
$$

and when $k_{\mathrm{d}}=0, R_{202}^{199}(t)$ is given by eq $6 \mathrm{~b}$ :

$$
\begin{aligned}
R_{202}^{199}(t) & =\frac{\left[\mathrm{Me}^{199} \mathrm{Hg}\right]_{t}}{\left[\mathrm{Me}^{202} \mathrm{Hg}\right]_{t}} \\
& =\frac{k_{\mathrm{m}}\left[{ }^{199} \mathrm{Hg}^{2+}\right]_{0} t+\left[\mathrm{Me}^{199} \mathrm{Hg}\right]_{0}}{k_{\mathrm{m}}\left[{ }^{202} \mathrm{Hg}^{2+}\right]_{0} t+\left[\mathrm{Me}^{202} \mathrm{Hg}\right]_{0}}
\end{aligned}
$$

where $\left[\mathrm{Me}^{m} \mathrm{Hg}\right]_{0}(m=199,201$, or 202$)$ is the concentration of $m$ isotope $\mathrm{MeHg}$ at day 0 (nanograms per liter); $\left[\mathrm{Me}^{m} \mathrm{Hg}\right]_{t}$ is the concentration of $m$ isotope $\mathrm{MeHg}$ at time $t$ (nanograms per liter); and $\left[{ }^{199} \mathrm{Hg}^{2+}\right]_{0}$ and $\left[{ }^{202} \mathrm{Hg}^{2+}\right]_{0}$ are the concentrations of ${ }^{199} \mathrm{Hg}^{2+}$ and ${ }^{202} \mathrm{Hg}^{2+}$ at day 0 (nanograms per liter).

Estimation of Net Production or Degradation Rate of $\mathrm{MeHg}$ in Everglades Soil, Floc, Periphyton, and Water. Net production or degradation rates of $\mathrm{MeHg}$ in soil, floc, periphyton, and water were estimated at the four management units of the Everglades [Loxahatchee National Wildlife Refuge (LNWR), Water Conservation Areas 2 and 3 (WCA 2 and WCA 3), and Everglades National Park (ENP)] by use of the measured methylation and demethylation rate constants $\left(k_{\mathrm{m}}\right.$ and $k_{\mathrm{d}}$ ) and net production or degradation rates $(R)$ (eqs $7 \mathrm{a}-8 \mathrm{e})$. Net $\mathrm{MeHg}$ production rates of ambient $\left[G_{\mathrm{X}}^{\mathrm{P}}(\right.$ ambient $\left.)\right]$ and newly input $\mathrm{Hg}^{2+}\left[G_{\mathrm{X}}^{\mathrm{P}}(\right.$ newly $\left.)\right]$ were calculated separately due to their difference in methylation/demethylation efficiency. The details in calculating the net $\mathrm{MeHg}$ production rate in each compartment can be found in Supporting Information.

$$
\begin{aligned}
& G_{\mathrm{X}}^{\mathrm{P}}(\text { ambient })=G_{\mathrm{X}}^{\mathrm{M}}(\text { ambient })-G_{\mathrm{X}}^{\mathrm{D}}(\text { ambient })=\frac{\bar{R}_{\mathrm{X}} M_{\mathrm{X}}}{A} \\
& R_{\mathrm{X}}=k_{\mathrm{m}}(\mathrm{X}) \alpha_{\mathrm{X}}\left[\mathrm{Hg}^{2+}\right]_{\mathrm{X}}-k_{\mathrm{d}}(\mathrm{X}) \beta_{\mathrm{X}}[\mathrm{MeHg}]_{\mathrm{X}} \\
& G_{\mathrm{X}}^{\mathrm{P}}(\text { newly })=\frac{\overline{k_{\mathrm{m}}(\mathrm{X})} \Delta\left[\mathrm{Hg}^{2+}\right]_{\mathrm{X}} M_{\mathrm{X}}}{A} \\
& G_{\mathrm{W}}^{\mathrm{P}}(\text { ambient })=G_{\mathrm{W}}^{\mathrm{M}}(\text { ambient })-G_{\mathrm{W}}^{\mathrm{D}}(\text { ambient }) \\
& G_{\mathrm{W}}^{\mathrm{M}}(\text { ambient })=\int_{0}^{D} \frac{\mathrm{d} C_{\mathrm{MeHg}}(Z)}{\mathrm{d} t} \mathrm{~d} Z \\
& =k_{\mathrm{M}} \Delta\left[\mathrm{Hg}^{2+}\right]_{\mathrm{W}} \operatorname{PAR}(0) \frac{1-\mathrm{e}^{-k_{\mathrm{PAR}} D}}{k_{\mathrm{PAR}}} \times 10^{3}
\end{aligned}
$$



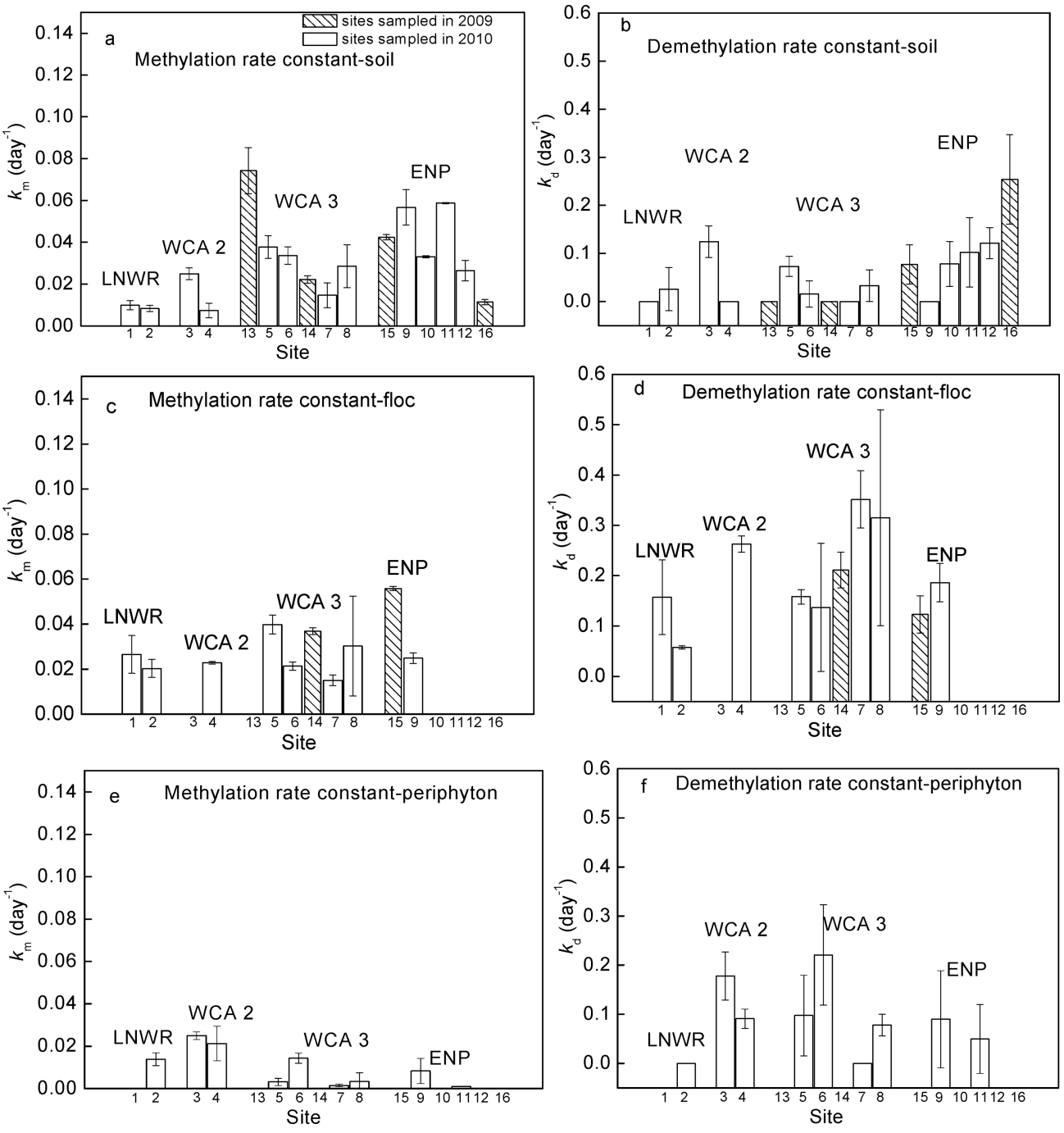

Figure 1. ${ }^{199} \mathrm{Hg}^{2+}$ methylation rate constant (per day) and $\mathrm{Me}^{201} \mathrm{Hg}$ demethylation rate constant (per day) in Everglades soil (a, b), floc (c, d), and periphyton (e, f). The $x$-axis represents the sampling sites. Sites $1-12$ were sampled in 2010, while sites 13-16 were sampled in 2009 . These sites were grouped according to their locations in the Everglades, from north to south. As samples of floc and periphyton could not be collected at some sites, $k_{\mathrm{m}}$ and $k_{\mathrm{d}}$ of these two compartments were not available at all sampling sites. Error bars represent the difference between triplicate samples.

$$
\begin{aligned}
k_{\mathrm{M}}=\frac{k_{\mathrm{m}}}{\mathrm{PAR}} & \\
G_{\mathrm{W}}^{\mathrm{D}}(\text { ambient })= & \sum_{\mathrm{I}}\left(k_{\mathrm{D}}(\mathrm{I})[\mathrm{MeHg}]_{\mathrm{W}} \operatorname{PAR}(0) \frac{1-\mathrm{e}^{-k_{\mathrm{I}} D}}{k_{\mathrm{I}}}\right. \\
& \left.\times 10^{3}\right) \\
G_{\mathrm{W}}^{\mathrm{P}}(\text { newly })= & \int_{0}^{D} \frac{\mathrm{d}_{\mathrm{MeHg}}(Z)}{\mathrm{d} t} \mathrm{~d} Z \\
= & k_{\mathrm{M}} \Delta\left[\mathrm{Hg}^{2+}\right]_{\mathrm{W}} \operatorname{PAR}(0) \frac{1-\mathrm{e}^{-k_{\mathrm{PAR}} D}}{k_{\mathrm{PAR}}} \times 10^{3}
\end{aligned}
$$

$G_{\mathrm{X}}^{\mathrm{P}}($ ambient $)$ and $G_{\mathrm{X}}^{\mathrm{P}}($ newly) are the net $\mathrm{MeHg}$ production or degradation rates of ambient and newly input $\mathrm{Hg}^{2+}$ in compartment $\mathrm{X}$ (nanograms per square meter per day), where $\mathrm{X}$ represents a specific compartment (soil, $\mathrm{S}$; floc, $\mathrm{F}$; periphyton, P; or water, $\mathrm{W}) ; G_{\mathrm{X}}^{\mathrm{M}}($ ambient $)$ and $G_{\mathrm{X}}^{\mathrm{D}}($ ambient $)$ are the specific production or degradation rates of ambient $\mathrm{MeHg}$ in compartment $\mathrm{X}$ (nanograms per square meter per day); Superscripts $\mathrm{M}$ and $\mathrm{D}$ in $G_{\mathrm{X}}^{\mathrm{M}}$ and $G_{\mathrm{X}}^{\mathrm{D}}$ mean methylation and demethylation of $\mathrm{Hg}$, respectively; $\bar{R}_{\mathrm{X}}$ is the average net production or degradation rate of ambient $\mathrm{MeHg}$ (nanograms per gram per day); $\alpha_{\mathrm{X}}$ is the ratio of methylation rate constant of ambient to newly spiked $\mathrm{Hg}$ for compartment $\mathrm{X} ; \beta_{\mathrm{X}}$ is the ratio of demethylation rate constant of ambient to newly spiked $\mathrm{MeHg} ; M_{\mathrm{X}}$ is the mass of compartment $\mathrm{X}$ in a specific management unit of the Everglades (grams); $A$ is the area of a specific management unit in the Everglades (square meters); $\left[\mathrm{Hg}^{2+}\right]_{\mathrm{X}}$ and $[\mathrm{MeHg}]_{\mathrm{X}}$ are the concentrations of $\mathrm{Hg}^{2+}$ and $\mathrm{MeHg}$ in compartment $\mathrm{X}$ (nanograms per gram or nanograms per liter); $\Delta\left[\mathrm{Hg}^{2+}\right]_{\mathrm{X}}$ is the per-day increased concentration of $\mathrm{Hg}^{2+}$ in compartment $\mathrm{X}$ by newly input $\mathrm{Hg}$ (nanograms per gram or nanograms per liter); PAR is the photosynthetically active radiation (Einstein per square meter per day); $\operatorname{PAR}(0)$ is the photosynthetically active radiation above the surface of the water (Einstein per square meter per day); $Z$ is a specific depth of water (meters); $k_{\mathrm{D}}(\mathrm{I})$ is the photodegradation constant of I type of sunlight with respect to $\operatorname{PAR}(0)$ (square meter per Einstein), where I represents UV-A (I = UV-A), UV-B ( I = UV- 

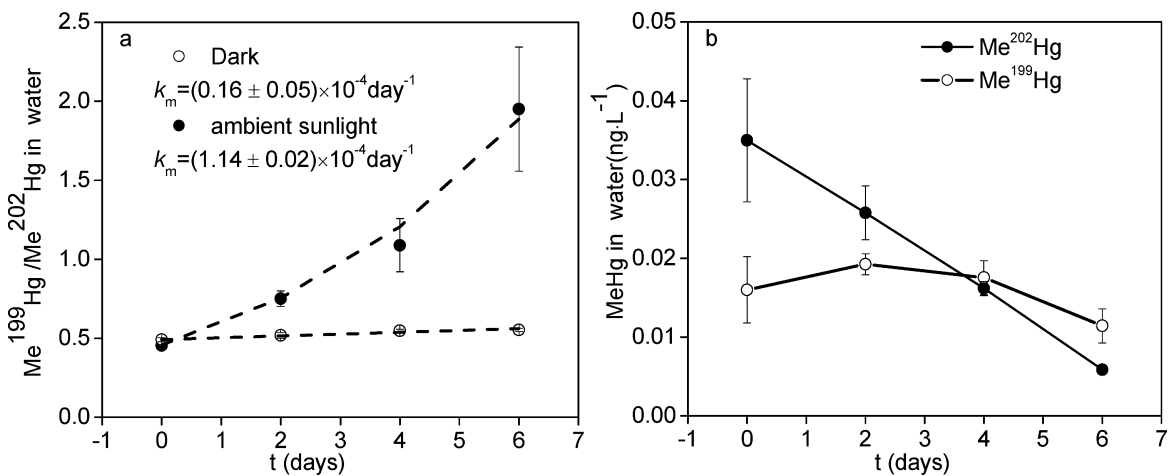

Figure 2. Variation of $\mathrm{Me}^{199} \mathrm{Hg} / \mathrm{Me}{ }^{202} \mathrm{Hg}$ ratio (a) and concentrations of $\mathrm{Me}^{199} \mathrm{Hg}$ and $\mathrm{Me}^{202} \mathrm{Hg}$ (b) during the incubation of Everglades water. $\mathrm{Me}^{199} \mathrm{Hg} / \mathrm{Me}^{202} \mathrm{Hg}$ ratio was used to calculate the methylation rate constant of spiked ${ }^{199} \mathrm{Hg}^{2+}$ (eq $\left.6 \mathrm{a}, 6 \mathrm{~b}\right)$. Points in panel (a) represent the measured values, while the dashed line shows the simulated results.

B), or visible sunlight ( $=$ PAR); $k_{\mathrm{I}}$ is the light attenuation coefficient of I type of sunlight (per meter); $D$ is the water depth (meters); and $k_{\mathrm{M}}$ is the PAR normalized rate constant of $\mathrm{MeHg}$ photomethylation (square meter per Einstein).

Statistical Analysis. Linear regression of $\mathrm{MeHg}$ concentrations in Everglades soil, floc, periphyton, and surface water on methylation and demethylation related variables in these compartments were conducted with Origin 6.0. Outliers were detected by Cook's distance measurements with SPSS (version 17 for Windows, SPSS Inc., Chicago, IL).

Pearson correlation analyses between $\mathrm{MeHg}$ concentration in water $\left(\mathrm{MeHg}_{\text {water }}\right)$ and 15 biogeochemical parameters were performed by using SPSS (version 17 for Windows, SPSS Inc., Chicago, IL). The 15 parameters included $\mathrm{MeHg}$ degradation potential $\left(P_{\mathrm{PD}}\right.$, a previously defined photodemethylation-related parameter), ${ }^{9}$ dissolved organic carbon (DOC), $\mathrm{MeHg}$ concentration in floc layer $\left(\mathrm{MeHg}_{\text {floc }}\right), \mathrm{MeHg}$ concentration in soil $\left(\mathrm{MeHg}_{\text {soil }}\right), \mathrm{MeHg}$ concentration in periphyton $\left(\mathrm{MeHg}_{\text {peri }}\right)$, nitrate $\left(\mathrm{NO}_{3}-\mathrm{N}\right)$, chlorophyll $a(\mathrm{Chl}-\mathrm{a})$, sulfate $\left(\mathrm{SO}_{4}-\mathrm{S}\right), \mathrm{H}_{2} \mathrm{~S}$, total $\mathrm{Hg}$ concentration in water $\left(\mathrm{THg}_{\text {water }}\right)$, temperature $(\mathrm{T})$, dissolved oxygen (DO), $\mathrm{pH}$, Turbidity (Turb), and soluble reductive phosphate (SRP). Multiple linear regression analyses of $\mathrm{MeHg}$ against the parameters significantly correlated with $\mathrm{MeHg}$ were conducted by using SPSS.

\section{RESULTS AND DISCUSSION}

$\mathrm{Hg}^{2+}$ Methylation and MeHg Demethylation Potential in Everglades Soil, Floc, Periphyton, and Surface Water. Figure 1 illustrates the methylation rate constants of spiked ${ }^{199} \mathrm{Hg}^{2+}\left(k_{\mathrm{m}}\right)$ and the demethylation rate constants of spiked $\mathrm{Me}^{201} \mathrm{Hg}\left(k_{\mathrm{d}}\right)$ in Everglades soil, floc, and periphyton. Significant methylation $(p<0.05)$ of the spiked ${ }^{199} \mathrm{Hg}^{2+}$ (0.01-0.07 day $^{-1}$, average $0.03 \pm 0.02$ day $^{-1}$ ) was observed in all incubated soil samples (Figure 1a). Soil $k_{\mathrm{m}}$ values in the two northern areas (LNWR and WCA 2) were lower than that in the two southern areas (WCA 3 and ENP). Soil $k_{\mathrm{d}}$ was in the range of $0-0.25 \mathrm{day}^{-1}$ (average $0.05 \pm 0.05 \mathrm{day}^{-1}$ ) and generally illustrated an increasing trend from north to south (Figure $1 \mathrm{~b}$ ). Both $k_{\mathrm{m}}$ and $k_{\mathrm{d}}$ were significantly higher than 0 in all floc samples (Figure 1c,d). Values of floc $k_{\mathrm{m}}(0.02-0.06$ day $^{-1}$, average $\left.0.03 \pm 0.01 \mathrm{day}^{-1}\right)$ were similar $(p>0.1)$ to that of soil, while floc $k_{\mathrm{d}}\left(0.06-0.35 \mathrm{day}^{-1}\right.$, average $0.20 \pm 0.09$ $\mathrm{day}^{-1}$ ) was much higher (about 3.5 times) than that of soil. No significant spatial distribution trend was shown for floc methylation and demethylation. Significant methylation of $\mathrm{Hg}^{2+}$ (0.001-0.02 day ${ }^{-1}$, average $0.01 \pm 0.01 \mathrm{day}^{-1}$ ) and demethylation of $\mathrm{MeHg}\left(0-0.22 \mathrm{day}^{-1}\right.$, average $0.09 \pm 0.07$ $\mathrm{day}^{-1}$ ) were also found in periphyton (Figure 1e,f). The potential $\mathrm{Hg}$ methylation $\left(k_{\mathrm{m}}\left[\mathrm{Hg}^{2+}\right]\right.$ ) and demethylation $\left(k_{\mathrm{d}}[\mathrm{MeHg}]\right)$ rates were further calculated and are shown in Figure S2 and Table S1 in Supporting Information. Potential methylation rates were $4.52 \pm 0.67 \mathrm{ng} \cdot \mathrm{g}(\mathrm{dry})^{-1} \cdot \mathrm{day}^{-1}$ in soil, $3.07 \pm 0.50 \mathrm{ng} \cdot \mathrm{g}(\mathrm{dry})^{-1} \cdot \mathrm{day}^{-1}$ in floc, and $0.54 \pm 0.13$ $\mathrm{ng} \cdot \mathrm{g}(\mathrm{dry})^{-1} \cdot \mathrm{day}^{-1}$ in periphyton. Potential demethylation rates were estimated to be $0.04 \pm 0.02 \mathrm{ng} \cdot \mathrm{g}(\mathrm{dry})^{-1} \cdot \mathrm{day}^{-1}$ (soil), 0.51 $\pm 0.15 \mathrm{ng} \cdot \mathrm{g}(\mathrm{dry})^{-1} \cdot \mathrm{day}^{-1}$ (floc), and $0.44 \pm 0.18 \mathrm{ng} \cdot \mathrm{g}$ $(\text { dry })^{-1} \cdot$ day $^{-1}$ (periphyton). Values of $k_{\mathrm{m}}$ and $k_{\mathrm{d}}$ obtained in this study are comparable to the values reported in previous studies conducted at WCA 2 and WCA 3 of the Everglades. $^{12,18,19,28}$ Compared to other ecosystems (Table S1, Supporting Information), methylation rate constants in Everglades soil, floc, and periphyton were at the high end of the range of this parameter, while moderate values of demethylation rate constants were observed in the Everglades. In comparison to the potential methylation rate of spiked ${ }^{199} \mathrm{Hg}^{2+}$, the net methylation rate of the ambient $\mathrm{Hg}$ was much smaller ( $<5 \%$ in soil; Table S1, Supporting Information). In addition, a large difference was observed between the estimated overall $\mathrm{MeHg}$ production rate $\left(k_{\mathrm{m}}\left[\mathrm{Hg}^{2+}\right]-\right.$ $\left.k_{\mathrm{d}}[\mathrm{MeHg}]\right)$ and the measured net production rate of ambient $\mathrm{MeHg}$ production rates (determined by $\mathrm{Me}^{202} \mathrm{Hg}$ ) (Table S1, Supporting Information), indicating that there are significant differences between ambient and newly input $\mathrm{Hg}$ species in methylation or demethylation efficiency. As periphyton is an important food source for externally feeding macroinvertebrates and fishes, methylation of mercury in periphyton may have a significant effect on the bioaccumulation of $\mathrm{MeHg}$ in the food chain.

Figure 2a shows the methylation of spiked ${ }^{199} \mathrm{Hg}^{2+}$ in surface water. The 199/202 ratio of $\mathrm{MeHg}$ increased gradually from 0.5 to $\sim 2$ after 6 days of exposure to sunlight, while negligible change occurred in the dark. To further validate the effect of sunlight on methylation, $k_{\mathrm{m}}$ values at trials with and without sunlight were calculated according to eq $6 \mathrm{a}, 6 \mathrm{~b}$. The ${ }^{199} \mathrm{Hg}^{2+}$ in water had a $k_{\mathrm{m}}$ of $(1.14 \pm 0.02) \times 10^{-4} \mathrm{day}^{-1}$ under ambient sunlight, while it was $(0.16 \pm 0.05) \times 10^{-4}$ day $^{-1}$ in the dark. These results suggest that methylation, which is dependent upon sunlight, occurs in Everglades water. However, its rate was much slower than that of $\mathrm{MeHg}$ photodemethylation $\left(k_{\mathrm{d}}=0.26\right.$ \pm 0.04 day $\left.^{-1}\right),{ }^{9}$ indicating that methylation in water plays a minor role in the cycling of $\mathrm{MeHg}$ in the Everglades. The changes in $\mathrm{Me}^{202} \mathrm{Hg}$ concentration were taken into account in 
order to correct for the effect of $\mathrm{MeHg}$ demethylation during the incubation. No significant increase in $\mathrm{Me}^{199} \mathrm{Hg}$ concentration was observed, but a substantial decrease in $\mathrm{Me}^{202} \mathrm{Hg}$ did occur (Figure $2 \mathrm{~b}$ ), due to the faster rate of photodemethylation compared to methylation. This indicates that contributions of the photodemethylation of ambient and newly produced $\mathrm{Me}^{199} \mathrm{Hg}$ were not negligible for the variation of $\mathrm{Me}^{199} \mathrm{Hg}$. These results suggest that photodegradation of ambient and newly produced $\mathrm{Me}^{199} \mathrm{Hg}$ should be considered when determining $k_{\mathrm{m}}$ in water, especially for systems with $k_{\mathrm{m}} \ll k_{\mathrm{d}}$.

Effects of MeHg Production and Degradation on the Spatial Distribution of $\mathrm{MeHg}$ in Everglades Soil, Floc, Periphyton and Surface Water. The importance of $\mathrm{MeHg}$ production and degradation in the spatial distribution of $\mathrm{MeHg}$ in various compartments of the Everglades was estimated by use of $k_{\mathrm{m}}$ and $k_{\mathrm{d}}$ values obtained in this study. The few previous studies on this topic focused only on the relationship between $\mathrm{MeHg}$ distribution in a compartment and its in situ methylation or demethylation. ${ }^{9,12}$ However, $\mathrm{MeHg}$ present in a particular compartment (e.g., water) could be determined by the methylation/demethylation that occurred both in that compartment and in other compartments (e.g., floc, periphyton, or soil). Thus, the relationships of $\mathrm{MeHg}$ in one compartment to the methylation/demethylation in that compartment and other compartments were evaluated in this study. Four parameters $\left(k_{\mathrm{m}}, k_{\mathrm{m}}\left[\mathrm{Hg}^{2+}\right], \quad k_{\mathrm{d}}\right.$ (or $P_{\mathrm{PD}}$ in water), and $k_{\mathrm{d}} / k_{\mathrm{m}}\left[\mathrm{Hg}^{2+}\right]$ ) associated with mercury methylation or demethylation were selected to study the effects of $\mathrm{MeHg}$ production and degradation on the spatial distribution of $\mathrm{MeHg} . k_{\mathrm{m}}$ and $k_{\mathrm{m}}\left[\mathrm{Hg}^{2+}\right]$ represent the potential and rate of methylation, while $k_{\mathrm{d}}$ (or $P_{\mathrm{PD}}$ in water) can reflect the demethylation potential of $\mathrm{MeHg}$. If spatial distribution of $\mathrm{MeHg}$ is significantly affected by methylation or demethylation, it is expected to be positively related to that of $k_{\mathrm{m}}$ and $k_{\mathrm{m}}\left[\mathrm{Hg}^{2+}\right]$ or negatively related to that of $k_{\mathrm{d}} \cdot k_{\mathrm{m}}$ and $k_{\mathrm{d}}$ were the two common parameters used to evaluate the influence of methylation and demethylation on $\mathrm{MeHg}$ distribution. However, neither of them can reflect the combined effect of $\mathrm{Hg}$ methylation and demethylation. This could be a problem if neither of these two processes can overrule the other. Under such conditions, the results could be inconclusive. Thus, a new parameter $\left(k_{\mathrm{d}} / k_{\mathrm{m}}\left[\mathrm{Hg}^{2+}\right]\right.$, the reciprocal of steady-state $\mathrm{MeHg}$ concentration) was derived (eqs 9 and 10) and used to represent the combined effect of methylation and demethylation. A negative relationship is expected to be observed between $\mathrm{MeHg}$ concentrations and $k_{\mathrm{d}}$ / $k_{\mathrm{m}}\left[\mathrm{Hg}^{2+}\right]$ if both methylation and demethylation significantly affect $\mathrm{MeHg}$ distribution. Regression analysis was then conducted to study the relationship between the $\mathrm{MeHg}$ present in soil, floc, or water and the values of the four parameters in these compartments (Figure S3, Supporting Information).

$$
\begin{aligned}
& \frac{\mathrm{d}[\mathrm{MeHg}]}{\mathrm{d} t}=k_{\mathrm{m}}\left[\mathrm{Hg}^{2+}\right]-k_{\mathrm{d}}[\mathrm{MeHg}] \\
& \frac{1}{[\mathrm{MeHg}]}=\frac{k_{\mathrm{d}}}{k_{\mathrm{m}}\left[\mathrm{Hg}^{2+}\right]}
\end{aligned}
$$

Except for site 1 (identified as an outlier), $\mathrm{MeHg}$ concentration in soil was closely correlated to $k_{\mathrm{m}}(p<0.05$; Figure S3a, Supporting Information) and $k_{\mathrm{m}}\left[\mathrm{Hg}^{2+}\right](p<0.01$; Figure S3b, Supporting Information) of soil. Other tested parameters did not show a significant effect on soil $\mathrm{MeHg}$ concentration $(p>0.1)$. Similar results were observed for periphyton (Figure S3d,e, Supporting Information, except for site 8 , which was identified as an outlier). These results suggest that $\mathrm{MeHg}$ concentrations in soil and periphyton are mainly related to the in situ methylation. Floc $\mathrm{MeHg}$ concentration was found to be inversely proportional to $k_{\mathrm{d}} / k_{\mathrm{m}}\left[\mathrm{Hg}^{2+}\right]$ of floc $(0.05<p<0.1$; Figure S3c, Supporting Information). Other tested parameters (including floc $k_{\mathrm{m}}$ and $k_{\mathrm{d}}$ ) did not show a significant effect on floc $\mathrm{MeHg}$ concentration $(p>0.1)$, indicating that both methylation and demethylation of $\mathrm{MeHg}$ in this compartment are important in controlling its $\mathrm{MeHg}$ concentration. The lack of a significant correlation between $\mathrm{MeHg}$ concentration and methylation or demethylation alone in floc suggests that neither of them dominates the other. For surface water, $\mathrm{MeHg}$ concentrations were strongly correlated to $k_{\mathrm{m}}(p<0.05$; Figure S3f, Supporting Information) and $k_{\mathrm{m}}\left[\mathrm{Hg}^{2+}\right](p<0.05$; Figure S3g, Supporting Information) of periphyton and $P_{\mathrm{PD}}$ of water column $(p<0.05$; Figure S3h, Supporting Information). $\mathrm{MeHg}$ in water was not positively affected by the methylation in floc and not significantly related to the other three parameters in floc $(p>0.1)$. In addition, $\mathrm{MeHg}$ in water showed no significant relationships to soil methylation/demethylation related parameters $(p>0.1)$. These results suggest that the methylation of mercury in periphyton and photodemethylation could significantly affect the levels of $\mathrm{MeHg}$ in Everglades water.

Cycling of $\mathrm{MeHg}$ in the Everglades water column is very complex as multiple processes could have a significant influence, for example, methylation in soil, floc, and periphyton and photodemethylation in the water column. Data obtained in this study and the monitoring investigation ${ }^{21}$ in 2005 were employed to further investigate factors influencing $\mathrm{MeHg}$ concentrations in water. Ten $\left(P_{\mathrm{PD}}, \mathrm{DOC}, \mathrm{MeHg}_{\text {floc }}, \mathrm{MeHg}_{\text {soil }}\right.$, $\mathrm{MeHg}_{\text {peri }}, \mathrm{SO}_{4}-\mathrm{S}, \mathrm{H}_{2} \mathrm{~S}, \mathrm{THg}_{\text {water }}, \mathrm{DO}$, and Turb) of the 15 environmental parameters were found to significantly correlate with $\mathrm{MeHg}$ concentrations in Everglades water $(p<0.01$ level). Multiple linear regression analyses indicated that $\mathrm{THg}_{\text {water }}$, $\mathrm{MeHg}_{\text {peri }}$, and $P_{\mathrm{PD}}$ were the three most important parameters influencing the distribution of $\mathrm{MeHg}_{\text {water }}$ (Table S2, Supporting Information), as implicated by their higher standardized coefficients $(\beta)$. With respect to the positive relationship of $\mathrm{MeHg}_{\text {water }}$ to $\mathrm{MeHg}_{\text {peri }}$ there are two possible explanations. One is that $\mathrm{MeHg}$ in periphyton is taken up or adsorbed from surface water and thus controlled by the concentration of surface water $\mathrm{MeHg}$. The other is that $\mathrm{MeHg}$ in water could be significantly affected by the methylation of $\mathrm{Hg}$ in periphyton. The latter explanation may be more reasonable in the Everglades, as a positive relationship of $\mathrm{MeHg}$ in periphyton to periphyton $k_{\mathrm{m}}$ was observed (Figure S3d,f, Supporting Information), meaning that $\mathrm{MeHg}_{\text {peri }}$ may reflect the $\mathrm{Hg}$ methylation in periphyton. These results suggest that methylation in periphyton and photodemethylation in water may influence the $\mathrm{MeHg}$ levels in Everglades water.

Production or Degradation of $\mathrm{MeHg}$ in Various Compartments of the Everglades. The net daily production (or degradation) rates of $\mathrm{MeHg}$ in soil, floc, periphyton, and water of the Everglades were estimated from the results of isotope addition experiments. Estimation of these rates is crucial in order to identify the major source and sink of $\mathrm{MeHg}$. As a difference in the efficiency of methylation or demethylation was expected to exist between ambient and newly input $\mathrm{Hg}$ species, the net production (or degradation) rates of newly input and ambient $\mathrm{Hg}$ species were calculated separately. The production rate of $\mathrm{MeHg}$ from the newly input 
Table 1. Net Production and Degradation Rates of MeHg in Various Compartments of Everglades ${ }^{a}$

\begin{tabular}{|c|c|c|c|c|}
\hline & \multicolumn{4}{|c|}{ net per-area production (or degradation) rate of $\mathrm{MeHg}\left(\mathrm{ng} \cdot \mathrm{m}^{-2} \cdot \mathrm{day}^{-1}\right)$} \\
\hline & LNWR & WCA 2 & WCA 3 & ENP \\
\hline \multicolumn{5}{|c|}{ Soil } \\
\hline$G_{S}^{\mathrm{P}}($ ambient $)$ & $418 \pm 289$ & $2105 \pm 1466$ & $3980 \pm 2621$ & $6236 \pm 8317$ \\
\hline$G_{S}^{\mathrm{P}}($ newly $)$ & $(5 \pm 0.6) \times 10^{-1}$ & $(9 \pm 7) \times 10^{-1}$ & $(18 \pm 11) \times 10^{-1}$ & $(21 \pm 10) \times 10^{-1}$ \\
\hline total & 418 & 2105 & 3982 & 6238 \\
\hline$\left[G_{S}^{\mathrm{P}}(\right.$ newly $\left.)\right] /$ total & $0.1 \%$ & $0.4 \%$ & $0.4 \%$ & $0.3 \%$ \\
\hline \multicolumn{5}{|c|}{ Floc } \\
\hline$G_{\mathrm{F}}^{\mathrm{P}}(\mathrm{ambient})$ & $-126 \pm 54$ & $-91 \pm 4$ & $-145 \pm 83$ & $-9 \pm 9$ \\
\hline$G_{\mathrm{F}}^{\mathrm{P}}($ newly $)$ & $(8 \pm 2) \times 10^{-2}$ & $(4 \pm 0.2) \times 10^{-2}$ & $(6 \pm 2) \times 10^{-2}$ & $(1 \pm 0.5) \times 10^{-2}$ \\
\hline total & -126 & -91 & -145 & -9 \\
\hline$\left[G_{\mathrm{F}}^{\mathrm{p}}(\right.$ newly $\left.)\right] /$ total & $0.06 \%$ & $0.04 \%$ & $0.04 \%$ & $0.1 \%$ \\
\hline \multicolumn{5}{|c|}{ Periphyton } \\
\hline$G_{\mathrm{P}}^{\mathrm{p}}($ ambient $)$ & $3 \pm 0.15$ & $52 \pm 22$ & $-9 \pm 10$ & $-27 \pm 23$ \\
\hline$G_{\mathrm{P}}^{\mathrm{P}}($ newly $)$ & $<1 \times 10^{-2}$ & $<1 \times 10^{-2}$ & $<1 \times 10^{-2}$ & $<1 \times 10^{-2}$ \\
\hline total & 3 & 52 & -9 & -27 \\
\hline$\left[G_{\mathrm{P}}^{\mathrm{p}}(\right.$ newly $\left.)\right] /$ total & $0.004 \%$ & $0.005 \%$ & $0.002 \%$ & $0.002 \%$ \\
\hline \multicolumn{5}{|c|}{ Water } \\
\hline$G_{\mathrm{W}}^{\mathrm{P}}($ ambient $)$ & $-5 \pm 6$ & $-4 \pm 2$ & $-4 \pm 3$ & $-4 \pm 3$ \\
\hline$G_{\mathrm{W}}^{\mathrm{P}}($ newly $)$ & $<1 \times 10^{-6}$ & $<1 \times 10^{-6}$ & $<1 \times 10^{-6}$ & $<1 \times 10^{-6}$ \\
\hline total & -5 & -4 & -4 & -4 \\
\hline$\left[G_{\mathrm{W}}^{\mathrm{P}}(\right.$ newly $\left.)\right] /$ total & $<0.0001 \%$ & $<0.0001 \%$ & $<0.0001 \%$ & $<0.0001 \%$ \\
\hline
\end{tabular}

${ }^{a}$ LNWR (Loxahatchee National Wildlife Refuge), WCA 2 and WCA 3 (Water Conservation Areas 2 and 3), and ENP (Everglades National Park) are the four management units of the Everglades. $G_{\mathrm{X}}^{\mathrm{P}}($ ambient $)$ and $G_{\mathrm{X}}^{\mathrm{P}}($ newly $)(\mathrm{X}=\mathrm{S}$, soil; F, floc; P, periphyton; or W, water) are the production rates of $\mathrm{MeHg}$ from ambient and newly input $\mathrm{Hg}$, respectively. $G_{\mathrm{X}}^{\mathrm{P}}\left(\right.$ newly) was calculated according to the average measured $k_{\mathrm{m}}$ in compartment $\mathrm{X}$ $\left[k_{\mathrm{m}}(\mathrm{X})\right]$ and the per-day increased concentration of $\mathrm{Hg}^{2+}$ by newly input $\mathrm{Hg}^{2+}\left(\Delta\left[\mathrm{Hg}^{2+}\right]_{\mathrm{X}}\right)($ eq $7 \mathrm{c})$. Values of $\Delta\left[\mathrm{Hg}^{2+}\right]_{\mathrm{X}}$ in each compartment were cited from ref 29.

$\mathrm{Hg}^{2+}$ can be estimated by using the $k_{\mathrm{m}}$ obtained from the spiked ${ }^{199} \mathrm{Hg}^{2+}$ (eq 7c). As for the production of $\mathrm{MeHg}$ from ambient $\mathrm{Hg}$, it would be ideal to calculate the net methylation rate from the measurement of changes in ambient $\mathrm{MeHg}$ if such measurement is feasible. However, significant changes in ambient $\mathrm{MeHg}$ could be detected only at limited sampling sites (14 of 16 for soil, 5 of 10 for floc, and 6 of 9 for periphyton) (Figure S4, Supporting Information). This is due to the fact that the variation in ambient $\mathrm{MeHg}\left(\mathrm{Me}^{202} \mathrm{Hg}\right.$ in this study) during the incubation period is often too small to be detected. Previous studies usually calculated the overall $\mathrm{MeHg}$ production rate by the difference of potential methylation rate and potential demethylation rate $\left(k_{\mathrm{m}}\left[\mathrm{Hg}^{2+}\right]-k_{\mathrm{d}}[\mathrm{MeHg}]\right){ }^{13,14}$ However, such practice does not take consideration of the differences in bioavailability of the ambient and newly spiked $\mathrm{Hg}$ species. In this study, $\alpha$ (ratio of methylation rate constant of ambient to newly spiked $\mathrm{Hg}$ ) and $\beta$ (ratio of demethylation rate constant of ambient to newly spiked $\mathrm{MeHg}$ ) in soil, floc, and periphyton were calculated by fitting the data of measured net $\mathrm{MeHg}$ production (or degradation) rate against the potential methylation rate $\left(k_{\mathrm{m}}\left[\mathrm{Hg}^{2+}\right]\right)$ and potential demethylation rate $\left(k_{\mathrm{d}}[\mathrm{MeHg}]\right)$ (eq $\left.7 \mathrm{~b}\right)$ of the limited sites where significant changes in ambient $\mathrm{MeHg}$ were observed (Figure S3, Supporting Information). $\alpha$ and $\beta$ were estimated to be 0.06 and 0.93 in soil, 0.02 and 0.71 in floc, and 0.53 and 0.50 in periphyton. The differences of ambient and newly spiked $\mathrm{Hg}$ species in methylation and demethylation were ignored in water, as the $\mathrm{MeHg}$ produced in water was negligible and no difference was observed in the photodemethylation of the ambient and newly spiked $\mathrm{MeHg}$. $^{27}$

By utilizing the obtained $\alpha, \beta$, and $k_{\mathrm{m}}$ and $k_{\mathrm{d}}$ values, the net production (or degradation) rates of ambient $\mathrm{MeHg}$ were estimated by use of eq $7 \mathrm{~b}$ at each site (Figure S5, Supporting
Information). Values of the other parameters for estimating the net production (or degradation) rates are listed in Table S3 (Supporting Information). Finally, the production (or degradation) rates of $\mathrm{MeHg}$ (from ambient or newly input $\mathrm{Hg}$ ) in soil, floc, periphyton, and water of the Everglades were estimated (see Table 1). Although the newly input $\mathrm{Hg}^{2+}$ has a much higher methylation/demethylation efficiency, the net daily produced $\mathrm{MeHg}$ from this source was found to account for a very small fraction of $\mathrm{MeHg}$ produced $(<0.4 \%)$. This could be explained by the low fraction of newly input $\mathrm{Hg}$ to the ambient $\mathrm{Hg}$ in the Everglades. Soil was estimated to be the largest source of $\mathrm{MeHg}$ in all four management units of the Everglades, accounting for $98-100 \%$ of total produced $\mathrm{MeHg}$. The net $\mathrm{MeHg}$ production rate in soil ranged from 418 to 6238 $\mathrm{ng} \cdot \mathrm{m}^{-2} \cdot \mathrm{day}^{-1}$, in the order LNWR $<$ WCA $2<\mathrm{WCA} 3<\mathrm{ENP}$. Floc is a major sink of $\mathrm{MeHg}$, with a degradation rate of -9 to $-145 \mathrm{ng} \cdot \mathrm{m}^{-2} \cdot \mathrm{day}^{-1}$. Water is another sink for $\mathrm{MeHg}$, accounting for approximately $2-10 \%$ of the total $\mathrm{MeHg}$ degradation. Periphyton was found to be a source for $\mathrm{MeHg}$ in the northern Everglades (LNWR and WCA 2) and a sink in the south (WCA 3 and ENP). The multiple role of periphyton in the Everglades is attributed to the great variety in periphyton $k_{\mathrm{m}}$ and $k_{\mathrm{d}}$ at different locations (Figure 1). It should be noted that each of the four areas of the Everglades (LNWR, WCA2, WCA3, and ENP) exhibits substantial spatial and temporal variation in factors (e.g., sulfide, sulfate, periphyton community), which could affect the production and degradation of MeHg. Given the limited sampling sites in this study, a relatively high standard deviation was observed for some estimated rates (Table 1$)$. In this study, soil $(0-10 \mathrm{~cm})$, floc, and periphyton samples were collected separately in order to compare the production of $\mathrm{MeHg}$ in these compartments, and then the samples were homogenized and incubated. By 
adopting this approach, the vertical distribution of sulfatereduction bacteria (SRB) activities in soil cores could not be reflected, which may cause some errors on the estimated production rates of $\mathrm{MeHg}$. However, these errors should be acceptable due to the fact that the obtained methylation rate constants of surface sediment in this study are comparable to the reported results of a previous study using the intact cores. ${ }^{12}$

There is a significant difference between the ambient and newly input $\mathrm{Hg}$ species in methylation/demethylation efficiency. However, this was often neglected in the previous studies of estimating the net $\mathrm{MeHg}$ production rate via isotope addition technique. ${ }^{13,14}$ If $\alpha$ and $\beta$ were not included in the estimation model, the estimated net production (or degradation) rate of $\mathrm{MeHg}$ in soil $\left[G_{\mathrm{S}}^{\mathrm{P}}(\mathrm{ambient})\right]$ could be overestimated by a factor of 20 (Table S4, Supporting Information). The average of the estimated net production (or degradation) rate of $\mathrm{MeHg}$ in floc $\left[G_{\mathrm{F}}^{\mathrm{P}}(\right.$ ambient $\left.)\right]$ would increase from -70 to $700 \mathrm{ng} \cdot \mathrm{m}^{-2} \cdot$ day $^{-1}$ (Table S4, Supporting Information). In that case, the net per-day increase in $\mathrm{MeHg}$ concentration in soil would account for $400 \%$ of ambient $\mathrm{MeHg}$ concentration (Table S4, Supporting Information). This fails to account for the mass balance of ambient $\mathrm{MeHg}$. This ratio is decreased to $20 \%$ if the estimated $\alpha$ and $\beta$ are included in the calculation. These results indicate that the difference in methylation/ demethylation efficiency of the ambient and newly input $\mathrm{Hg}$ species must be taken into account when net $\mathrm{MeHg}$ production (or degradation) rates are estimated. In the Everglades, values of $\alpha$ were much lower than that of $\beta$ in the soil and floc, suggesting the dissimilarities of ambient $\mathrm{MeHg}$ and inorganic $\mathrm{Hg}$ in bioavailability. ${ }^{15} \mathrm{~A}$ much higher value of $\alpha$ was observed in periphyton $(51 \%)$ in comparison to soil and floc $(2-6 \%)$. This may be caused by the differences in absorbing divalent inorganic $\mathrm{Hg}$ and/or speciation of divalent inorganic $\mathrm{Hg}$ in these compartments, which could significantly affect the bioavailability of inorganic $\mathrm{Hg}$.

In order to identify the major source of $\mathrm{MeHg}$ in the water column, the distribution rate of daily produced $\mathrm{MeHg}$ in the benthic layer to the water column was estimated. The rate in each management unit of the Everglades was calculated from the previously reported percentage of produced $\mathrm{MeHg}$ distributed to the compartments in water column ${ }^{29}$ and the net $\mathrm{MeHg}$ production rates measured in this study (see details in Supporting Information). By using a mass balance model of $\mathrm{MeHg}$, it was estimated that approximately 5.9\% (LNWR), $20.8 \%$ (WCA 2), $15.2 \%$ (WCA 3), and 9.4\% (ENP) of produced $\mathrm{MeHg}$ was transported into the compartments in the water column. ${ }^{29}$ The rate of totally produced $\mathrm{MeHg}$ distributed to the compartments in the water column were estimated to be $17 \mathrm{ng} \cdot \mathrm{m}^{-2} \cdot \mathrm{day}^{-1}$ (LNWR), $429 \mathrm{ng} \cdot \mathrm{m}^{-2} \cdot \mathrm{day}^{-1}$ (WCA 2), 581 $\mathrm{ng} \cdot \mathrm{m}^{-2} \cdot \mathrm{day}^{-1}$ (WCA 3), and $582 \mathrm{ng} \cdot \mathrm{m}^{-2} \cdot \mathrm{day}^{-1}$ (ENP). Methylation in periphyton was then estimated to account for $18 \%$ (LNWR) and 12\% (WCA 2) of total produced $\mathrm{MeHg}$ imported into the water column, with the rest coming from the soil. These results suggest that soil could be the largest source for $\mathrm{MeHg}$ in the water column, while methylation in periphyton could also contribute significantly in the northern Everglades. From the estimated net methylation rate in periphyton (Table 1), the daily production of $\mathrm{MeHg}$ by periphyton was calculated to be 0.02 and $0.30 \mathrm{~kg}$ in the LNWR and WCA 2, respectively. These amounts accounted for approximately $10 \%$ and $140 \%$ of ambient $\mathrm{MeHg}$ in the water of these two management units $(0.19$ and $0.22 \mathrm{~kg}){ }^{23}$ This estimation also supports the opinion that methylation in periphyton can significantly influence the levels of $\mathrm{MeHg}$ in Everglades surface water. Transport of mercury at the sediment-water interface is a complicated process and could be affected by many factors, such as methylation, redox condition, water depth, and physical properties of the sediments. $^{30,31}$ In consideration of the complexity of this process, results obtained in this study could be further refined by measuring and comparing the transport rates of $\mathrm{MeHg}$ from benthic layer and periphyton to water column.

Sulfate-reducing bacteria were deemed to be the methylators in Everglades soil, floc, and periphyton. ${ }^{12,18}$ Sulfate, sulfide, nutrients, and dissolved organic matter (DOM) concentrations generally bear a decreasing gradient from north to south. ${ }^{21,32}$ Sulfate can stimulate the activity of SRB and thus favor the $\mathrm{Hg}$ methylation process, while high sulfide would inhibit this process by reducing the bioavailability of $\mathrm{Hg}^{2+33}$ DOM can either enhance the methylation process by stimulating SRB activity $^{34}$ or inhibit it via reducing $\mathrm{Hg}$ bioavailability. ${ }^{35}$ The spatial distribution of these parameters may result in the variation of $\mathrm{MeHg}$ production rate in the Everglades. As the addition of sulfide was observed to inhibit the methylation of $\mathrm{Hg}^{2+}$ in the Everglades, ${ }^{12}$ the north-to-south decreasing trend of sulfide may explain the larger methylation rate constants of $\mathrm{Hg}$ in the two southern areas of the Everglades. In addition, the composition of Everglades periphyton varies across the Everglades, ranging from filamentous green mats in the eutrophic areas to calcareous mats in less impacted areas. ${ }^{18,36}$ It was found from a previous study that the filamentous green algal communities showed a more rapid rate of sulfate reduction compared to the calcareous periphyton, ${ }^{18}$ indicating the high activity of SRB in the filamentous green algal communities. It could explain the decrease of periphyton methylation rate from north to south following a decreasing trend of nutrients.

\section{ASSOCIATED CONTENT}

\section{Supporting Information}

Additional text and equations, five figures, and four tables as described in the text. This material is available free of charge via the Internet at http://pubs.acs.org/ .

\section{AUTHOR INFORMATION}

\section{Corresponding Author}

*Telephone:305-348-6210; fax: 305-348-3772; e-mail: cai@fiu. edu.

\section{Notes}

The authors declare no competing financial interest.

\section{ACKNOWLEDGMENTS}

We thank Dr. Joel Trexler, Aaron Parker, Carlos Tudela, and Justin Dummitt at FIU for their help with sample collection. We thank Dr. Leonard J. Scinto at FIU for providing the instrument for the PAR measurement. This research was partially supported by the U.S. Department of Energy (DEFG01-05EW07033) and by the National Natural Science Foundation of China (21120102040). This is contribution No. 553 of the Southeast Environmental Research Center at FIU. 


\section{REFERENCES}

(1) Compeau, G. C.; Bartha, R. Sulfate-reducing bacteria: principal methylators of mercury in anoxic estuarine sediment. Appl. Environ. Microbiol. 1985, 50 (2), 498-502.

(2) Kerin, E. J.; Gilmour, C. C.; Roden, E.; Suzuki, M. T.; Coates, J. D.; Mason, R. P. Mercury methylation by dissimilatory iron-reducing bacteria. Appl. Environ. Microbiol. 2006, 72 (12), 7919-7921.

(3) Gilmour, C. C.; Henry, E. A. Mercury methylation by sulfatereducing bacteria: biogeochemical and pure culture studies. Abstracts of Papers, American Chemical Society Meeting, San Francisco, CA, 1992.

(4) Gray, J. E.; Hines, M. E. Biogeochemical mercury methylation influenced by reservoir eutrophication, Salmon Falls Creek Reservoir, Idaho, USA. Chem. Geol. 2009, 258 (3-4), 157-167.

(5) Mitchell, C. P. J.; Gilmour, C. C. Methylmercury production in a Chesapeake Bay salt marsh. J. Geophys. Res., [Biogeosci.] 2008, 113, No. G00C04.

(6) Tsui, M. T. K.; Finlay, J. C.; Nater, E. A. Effects of stream water chemistry and tree species on release and methylation of mercury during litter decomposition. Environ. Sci. Technol. 2008, 42 (23), 8692-8697.

(7) Zizek, S.; Guevara, S. R.; Horvat, M. Validation of methodology for determination of the mercury methylation potential in sediments using radiotracers. Anal. Bioanal. Chem. 2008, 390 (8), 2115-2122.

(8) Hammerschmidt, C. R.; Fitzgerald, W. F. Photodecomposition of methylmercury in an arctic Alaskan lake. Environ. Sci. Technol. 2006, 40 (4), 1212-1216.

(9) Li, Y. B.; Mao, Y. X.; Liu, G. L.; Tachiev, G.; Roelant, D.; Feng, X. B.; Cai, Y. Degradation of methylmercury and its effects on mercury distribution and cycling in the Florida Everglades. Environ. Sci. Technol. 2010, 44 (17), 6661-6666.

(10) Lehnherr, I.; St. Louis, V. L.; Hintelmann, H.; Kirk, J. L. Methylation of inorganic mercury in polar marine waters. Nat. Geosci. 2011, 4 (5), 298-302.

(11) Siciliano, S. D.; O’Driscoll, N. J.; Tordon, R.; Hill, J.; Beauchamp, S.; Lean, D. R. S. Abiotic production of methylmercury by solar radiation. Environ. Sci. Technol. 2005, 39 (4), 1071-1077.

(12) Gilmour, C. C.; Riedel, G. S.; Ederington, M. C.; Bell, J. T.; Benoit, J. M.; Gill, G. A.; Stordal, M. C. Methylmercury concentrations and production rates across a trophic gradient in the northern Everglades. Biogeochemistry 1998, 40, 327-345.

(13) Gray, J. E.; Hines, M. E.; Biester, H. Mercury methylation influenced by areas of past mercury mining in the Terlingua district, Southwest Texas, USA. Appl. Geochem. 2006, 21 (11), 1940-1954.

(14) Gray, J. E.; Hines, M. E.; Higueras, P. L.; Adatto, I.; Lasorsa, B. $\mathrm{K}$. Mercury speciation and microbial transformations in mine wastes, stream sediments, and surface waters at the Almaden Mining District, Spain. Environ. Sci. Technol. 2004, 38 (16), 4285-4292.

(15) Hintelmann, H.; Keppel-Jones, K.; Evans, R. D. Constants of mercury methylation and demethylation rates in sediments and comparison of tracer and ambient mercury availability. Environ. Toxicol. Chem. 2000, 19 (9), 2204-2211.

(16) Drott, A.; Lambertsson, L.; Bjorn, E.; Skyllberg, U. Do potential methylation rates reflect accumulated methyl mercury in contaminated sediments? Environ. Sci. Technol. 2008, 42 (1), 153-158.

(17) Eckley, C. S.; Hintelmann, H. Determination of mercury methylation potentials in the water column of lakes across Canada. Sci. Total Environ. 2006, 368 (1), 111-125.

(18) Cleckner, L. B.; Gilmour, C. C.; Hurley, J. P.; Krabbenhoft, D. P. Mercury methylation in periphyton of the Florida Everglades. Limnol. Oceanogr. 1999, 44 (7), 1815-1825.

(19) Marvin-DiPasquale, M. C.; Oremland, R. S. Bacterial methylmercury degradation in Florida Everglades peat sediment. Environ. Sci. Technol. 1998, 32 (17), 2556-2563.

(20) Vaithiyanathan, P.; Richardson, C. J.; Kavanaugh, R. G.; Craft, C. B.; Barkay, T. Relationships of eutrophication to the distribution of mercury and to the potential for methylmercury production in the peat soils of the everglades. Environ. Sci. Technol. 1996, 30 (8), 2591-2597.
(21) Stober, Q. J.; Thornton, K.; Jones, R.; Richards, J.; Ivey, C.; Welch, R.; Madden, M.; Trexler, J.; Gaiser, E.; Scheidt, D.; Rathbun, S. South Florida Ecosystem Assessment: Phase I/II (Technical Report).Everglades Stressor Interactions: Hydropatterns, Eutrophication, Habitat Alteration, and Mercury Contamination; U.S. EPA Region 4: Athens, GA, 2001.

(22) Martin-Doimeadios, R. C. R.; Stoichev, T.; Krupp, E.; Amouroux, D.; Holeman, M.; Donard, O. F. X. Micro-scale preparation and characterization of isotopically enriched monomethylmercury. Appl. Organomet. Chem. 2002, 16 (10), 610-615.

(23) Liu, G. L.; Cai, Y.; Philippi, T.; Kalla, P.; Scheidt, D.; Richards, J.; Scinto, L.; Appleby, C. Distribution of total and methylmercury in different ecosystem compartments in the Everglades: Implications for mercury bioaccumulation. Environ. Pollut. 2008, 153 (2), 257-265.

(24) Mao, Y. X.; Liu, G. L.; Meichel, G.; Cai, Y.; Jiang, G. B. Simultaneous speciation of monomethylmercury and monoethylmercury by aqueous phenylation and purge-and-trap preconcentration followed by atomic spectrometry detection. Anal. Chem. 2008, 80 (18), 7163-7168.

(25) Hintelmann, H.; Evans, R. D. Application of stable isotopes in environmental tracer studies: Measurement of monomethylmercury $\left(\mathrm{CH}_{3} \mathrm{Hg}^{+}\right)$by isotope dilution ICP-MS and detection of species transformation. Fresenius' J. Anal. Chem. 1997, 358 (3), 378-385.

(26) De Laeter, J. R.; Bohlke, J. K.; De Bievre, P.; Hidaka, H.; Peiser, H. S.; Rosman, K. J. R.; Taylor, P. D. P. Atomic weights of the elements: Review 2000 (IUPAC technical report). Pure Appl. Chem. 2003, 75 (6), 683-800.

(27) Lehnherr, I., St.; Louis, V. L. Importance of ultraviolet radiation in the photodemethylation of methylmercury in freshwater ecosystems. Environ. Sci. Technol. 2009, 43 (15), 5692-5698.

(28) Marvin-DiPasquale, M.; Agee, J.; McGowan, C.; Oremland, R. S.; Thomas, M.; Krabbenhoft, D.; Gilmour, C. C. Methyl-mercury degradation pathways: A comparison among three mercury-impacted ecosystems. Environ. Sci. Technol. 2000, 34 (23), 4908-4916.

(29) Liu, G. L.; Naja, G. M.; Kalla, P.; Scheidt, D.; Gaiser, E.; Cai, Y. Legacy and fate of mercury and methylmercury in the Florida Everglades. Environ. Sci. Technol. 2011, 45 (2), 496-501.

(30) Mason, R. P.; Kim, E. H.; Cornwell, J.; Heyes, D. An examination of the factors influencing the flux of mercury, methylmercury and other constituents from estuarine sediment. Mar. Chem. 2006, 102 (1-2), 96-110.

(31) Gill, G. A.; Bloom, N. S.; Cappellino, S.; Driscoll, C. T.; Dobbs, C.; McShea, L.; Mason, R.; Rudd, J. W. M. Sediment-water fluxes of mercury in Lavaca Bay, Texas. Environ. Sci. Technol. 1999, 33 (5), 663-669.

(32) Scheidt, D. J.; Kalla, P. I. Everglades ecosystem assessment: water management and quality, eutrophication, mercury contamination, soils and habitat; U.S. EPA Region 4: Athens, GA, 2007.

(33) Hammerschmidt, C. R.; Fitzgerald, W. F. Geochemical controls on the production and distribution of methylmercury in near-shore marine sediments. Environ. Sci. Technol. 2004, 38 (5), 1487-1495.

(34) St. Louis, V. L.; Rudd, J. W. M.; Kelly, C. A.; Beaty, K. G.; Bloom, N. S.; Flett, R. J. Importance of wetlands as sources of methyl mercury to boreal forest ecosystems. Can. J. Fish. Aquat. Sci. 1994, 51 (5), 1065-1076.

(35) Barkay, T.; Gillman, M.; Turner, R. R. Effects of dissolved organic carbon and salinity on bioavailability of mercury. Appl. Environ. Microbiol. 1997, 63 (11), 4267-4271.

(36) McCormick, P. V.; Rawlik, P. S.; Lurding, K.; Smith, E. P.; Sklar, F. H. Periphyton-water quality relationships along a nutrient gradient in the northern Florida Everglades. J. N. Am. Benthol. Soc. 1996, 15 (4), 433-449. 